\title{
STUDIES ON CAUSES OF ABORTION IN MAGHRABIAN CAMELS
}

\section{OSMAN, A. OSMAN ${ }^{1}$, H. A. EL-METWALY ${ }^{2}$, \\ A. A. WAHBA ${ }^{3}$ and SAMAH F. HEFNY ${ }^{4}$}

\author{
1. Veterinary Services Department (Bacteriology), Animal Production Research \\ Institute, ARC, Egypt. \\ 2. Camel Research Department, Animal Production Research Institute, ARC, Egypt. \\ 3. Parasitology Department, Animal Health Research Institute, ARC, Egypt. \\ 4. Chlamydia Unit, Animal Health Research Institute, ARC, Egypt.
}

(Manuscript received 26 September 2016)

\begin{abstract}
$\mathrm{H}$ istory of abortion, stillbirths and death of camel calves within 6 months of birth were appeared in the year of 2013 in Maghribian camels in a farm in Mersa Matrouh governorate. Whole blood and serum samples were collected from 34 camels $\geq 5$ years and from 19 camels $<5$ years. Blood films prepared for detection of blood parasites by Giemsa stain. Serum samples used for detection of Toxoplasma antibodies by slide Toxo-Latex agglutination test (LAT) and Chlamydophilla spp. antibodies were detected by complement fixation test (CFT). Fifteen internal organs (liver, heart, lung and spleen) from aborted calves and twenty vaginal swabs from she camels that aborted were collected for isolation of chlamydiae via inoculation in embryonated chicken eggs (ECE). Toxoplasma antibodies, Theileria, Anaplasma and mixed infection (Theileria and Anaplasma) were detected in $70.6 \%, 26.5 \%, 17.6 \%$ and $8.8 \%$ of camels $\geq 5$ years, while they were detected in $42.1 \%, 26.3 \%$, $10.5 \%$ and $5.3 \%$ of camels $<5$ years respectively. Examined serum samples by CFT showed $27 \%$ were positive for C. psittaci antibodies. Chlamydial inclusion bodies were detected in $45 \%$ and $20 \%$ of vaginal swabs and internal organs respectively by chicken embryo inoculation. Camels were treated with coliprim, butalex, imizol and alamycin which repeated routinely every 6 months. Number of aborted fetuses and stillbirths were decreased in years 2014 and 2015, while the number of still alive camel calves were increased in the same 2 years. No camel calves were dead within 6 months of birth in year 2015.
\end{abstract}

Key words: Camels, Abortion, Toxoplasma, Theileria, Anaplasma,

Chlamydia.

\section{INTRODUCTION}

Camels (Camelus dromedarius) are important multipurpose animals in many countries all over the world including Egypt. They are a source of meat, milk and hides production. Camels affected with various protozoal parasites such as Toxoplasma, Theileria and Anaplasma showed many symptoms including abortion, fetal death, infertility and decrease in milk yield. 
Toxoplasa gondii is a heteroxenous coccidian parasite. The definitive hosts are domestic cats and various species of wild felids. The intermediate hosts are mammals and birds (Elamin et al., 1992). T. gondii cause abortion, neonatal death and faetal abnormalities in animals and human (Hayde and Pollak, 2000 and Trees and Williams, 2005). Toxoplasmosis is a globally distributed zoonosis with serious impact on unborn fetuses and also immunosuppressed individuals (Klun et al., 2006). In Egypt Michael et al. (1977) and Hilali et al. (1998) reported toxoplasmosis in camels.

Theileriosis and anaplasmosis are tick born blood protozoal disease affecting camels. Theileria infection reported in camels in Egypt by El-Refaii et al. (1998) and El-Fayoumy et al. (2005). Ismael et al. (2014) found Theileria infection in Saudi Arabia in camels suffered from symptoms included abortion and/or infertility. Anaplasma infection recorded in camels in Saudi Arabia and Tunisia (Bastos et al., 2015 and Belkahia et al., 2015). A. marginale is highly pathogenic and abortion is one of the clinical symptoms appeared in ruminants and associated with fetal infection (UrdazRodríguez et al. 2009 and Hairgrove et al. 2015).

Chlamydophila spp. is a genus of Gram negative bacteria which has been reported as pathogenic in camels. Chalmydophila spp. is an ubiquitous parasite with mixed infections occurring frequently (Reinhold et al., 2011). Chlamydophilosis is a major cause of abortion in domestic ruminants and caused by Chlamydophila spp. (Aljumaah and Mansour, 2012). Camels could be infected with Chlamydophila, but most infected camels appear healthy so, they can play a very important role in transmission of this infection to contact animals.

The aim of the present work is to study the causes of the case history of abortion appeared in Maghribian camels in a farm in Mersa Matrouh governorate and how to control it.

\section{MATERIALS AND METHODS}

\section{History in the farm:}

In the year of 2013 a farm of Maghribian camels in Mersa Matrooh governorate suffered from abortion (5/19), stillbirths (3/19) and death of newly born camel calves within 6 months of birth (10/19). The number of still alive camel calves were only 1 from 19.

\section{Sample collection:}

At the beginning of the year 2014, blood samples for serum separation were collected in clean vacuotainer tubes from jugular vein of 34 camels $\geq 5$ years and 19 ones $<5$ years. Another blood samples from the same camels were collected in another clean tubes containing sodium salt of EDTA anticoagulant. The collected samples were sent to laboratory in ice box containing ice packs. For detection of chlamydial inclusion bodies, 15 internal organs (liver, heart, lung and spleen) from 
aborted calves were collected. The organs were kept in clean labeled plastic bags in deep freezer until used for egg inoculation. Also, 20 vaginal swabs were collected from aborted camels through sterile endocervical swabs. These swabs were kept into sterile tubes containing PBS and used for egg inoculation.

\section{Methodology:}

\section{Parasitological examination:}

Sera were separated by centrifugation at $3000 \mathrm{rpm}$ for 10 minutes and stored at $-20^{\circ} \mathrm{C}$ until use. Rapid qualitative detection of Toxoplasma antibodies was applied by slide Toxo-Latex agglutination test (LAT) using Toxo Latex kit (Cam Tech Medical, 4 Stable Crest, Bradford, West Yorshire, BD2 IE7, United Kingdom). The kit was used strictly following manufacturer instructions. Blood films were prepared, stained with Giemsa stain and examined microscopically for detection of blood parasites.

\section{Bacteriological examination:}

\section{1- Detection of $C$. psittaci antibodies in the collected serum samples by complement fixation test (CFT):}

CFT was conducted according to Edwin and Nathalie (1979) using amboceptor (anti-sheep red blood cell); reference antiserum and antigen of chlamydiae for CFT ( $C$. psittaci CF test Reagent "Seiken") supplied commercially from Denka Sieken Co., Ltd., Tokyo, Japan. Controls were included throughout the entire testing (complement control, positive known serum control and antigen control).

\section{2- Preparation of samples for inoculation of chicken embryo:}

Sterile vaginal swabs were collected from cases of abortion according to Black (1997). These swabs were placed into sterile tubes containing PBS (pH 7.5). The internal organs of each aborted camels were pooled and grinded in sterile mortar with sterile sand under aseptic conditions with the addition of PBS ( $\mathrm{pH} 7.5)$ and then centrifuged for $15 \mathrm{~min}$. at $3000 \mathrm{rpm}$. A clear supernatant fluid was transferred under aseptic condition using a sterile pipette to another centrifuge tube (Andersen, 1998). A stock solution of antibiotics (Sigma-Aldrich, MO, USA); streptomycin (1 mg/ml), vancomycin $(1 \mathrm{mg} / \mathrm{ml})$ and nystatin $(100$ units $/ \mathrm{ml})$ were added to inhibit microorganisms other than chlamydiae. The final supernatant was used for inoculation of the embryonated chicken egg through yolk sac route.

\section{3- Chicken embryo inoculation and staining of yolk sac using Gimenez stain:}

Procedure for isolation according to Pierre and Michel (1993). Seven days old specific pathogen free (SPF) fertile chicken eggs were used for detection of chlamydiae. Thirty five samples (15 internal organs and 20 vaginal swabs) were inoculated into the egg yolk sac and the inoculated eggs were incubated at $37^{\circ} \mathrm{C}$ in a humidified incubator. Non inoculated control eggs were labeled and incubated beside the inoculated eggs. The eggs were candled on a daily basis and the eggs that died 
within 3 days post inoculation were discarded while those died after day 3 to day 10 are opened. The yolk sac membranes were harvested and stained by Gimenez stain (Gimenez, 1964). Embryos of specific deaths were examined for gross changes and lesions specific for chlamydial infection.

\section{Treatment:}

A program of treatment of camels started at the beginning of 2014 and repeated routinely every 6 months. Camels treated for Toxoplasma infection with coliprim by intramuscular injection with $2.5 \mathrm{ml} / 40 \mathrm{~kg}$ body weight for 3 successive days (each $1 \mathrm{ml}$ contains $200 \mathrm{mg}$ sulphadiazine sodium and $40 \mathrm{mg}$ trimethoprim). For Theileria infection, camels treated with butalex by intramuscular injection with $1 \mathrm{ml} / 20$ $\mathrm{kg}$ body weight, 2 doses 72 hours apart (each $1 \mathrm{ml}$ contains $50 \mathrm{mg}$ buparvaquone) and for Anaplasma infection, they injected with imizol subcutaneously with $2 \mathrm{ml} / 100$ $\mathrm{kg}$ body weight (each $1 \mathrm{ml}$ contains $85 \mathrm{mg}$ imidocarb dipropionate). For Chlamydia infection, camels treated with alamycin by intramuscular injection with $1 \mathrm{ml} / 10 \mathrm{~kg}$ body weight (each $1 \mathrm{ml}$ contains $200 \mathrm{mg}$ oxytetracycline).

\section{RESULTS}

Table (1) showed that Toxoplasma antibodies were investigated in $70.6 \%(24 / 34)$ and $42.1 \%(8 / 19)$ of camels $\geq$ and $<5$ years respectively.

Concerning blood parasites in camels $\geq 5$ years, infection rates with Theileria (erythrocytic and/or schizonts), Anaplasma marginale and mixed infection were $26.5 \%$ $(9 / 34), 17.6 \%(6 / 34)$ and $8.8 \%(3 / 34)$ respectively. Camels $<5$ years showed infection with the same blood parasites with rates of $26.3 \%(5 / 19), 10.5 \%(2 / 19)$ and $5.3 \%(1 / 19)$ respectively. After treatment, blood parasites were not detected in old and young camels.

Table 1. Detection of Toxoplasma gondii antibodies and blood parasites in camels $\geq$ and $<5$ years.

\begin{tabular}{|c|c|c|c|c|c|c|c|}
\hline & \multirow{3}{*}{$\begin{array}{c}\text { Toxoplasma } \\
\text { gondii } \\
\text { by latex } \\
\text { agglutination } \\
\text { test } \\
\end{array}$} & \multicolumn{6}{|c|}{ Blood parasites detected } \\
\hline & & \multicolumn{2}{|c|}{ Theileria } & \multicolumn{2}{|c|}{ Anaplasma marginale } & \multicolumn{2}{|c|}{ Mixed infection* } \\
\hline & & $\begin{array}{l}\% \text { and } \\
\text { No. before } \\
\text { treatment }\end{array}$ & $\begin{array}{c}\% \text { and } \\
\text { No. after } \\
\text { treatment }\end{array}$ & $\begin{array}{l}\% \text { and } \\
\text { No. before } \\
\text { treatment }\end{array}$ & $\begin{array}{c}\% \text { and } \\
\text { No. after } \\
\text { treatment }\end{array}$ & $\begin{array}{l}\% \text { and } \\
\text { No. before } \\
\text { treatment }\end{array}$ & $\begin{array}{l}\% \text { and } \\
\text { No. after } \\
\text { treatment }\end{array}$ \\
\hline $\begin{array}{l}\text { Camels } \\
\geq 5 \\
\text { years }\end{array}$ & $\begin{array}{c}70.6 \% \\
(24 / 34)\end{array}$ & $\begin{array}{l}26.5 \% \\
(9 / 34)\end{array}$ & $\begin{array}{c}0 \% \\
(0 / 34)\end{array}$ & $\begin{array}{l}17.6 \% \\
(6 / 34)\end{array}$ & $\begin{array}{c}0 \% \\
(0 / 34)\end{array}$ & $\begin{array}{c}8.8 \% \\
(3 / 34)\end{array}$ & $\begin{array}{c}0 \% \\
(0 / 34)\end{array}$ \\
\hline $\begin{array}{l}\text { Camels } \\
<5 \\
\text { years } \\
\end{array}$ & $\begin{array}{l}42.1 \% \\
(8 / 19)\end{array}$ & $\begin{array}{l}26.3 \% \\
(5 / 19)\end{array}$ & $\begin{array}{c}0 \% \\
(0 / 19)\end{array}$ & $\begin{array}{l}10.5 \% \\
(2 / 19)\end{array}$ & $\begin{array}{c}0 \% \\
(0 / 19)\end{array}$ & $\begin{array}{c}5.3 \% \\
(1 / 19)\end{array}$ & $\begin{array}{c}0 \% \\
(0 / 19)\end{array}$ \\
\hline
\end{tabular}

* Theileria and Anaplasma marginale 


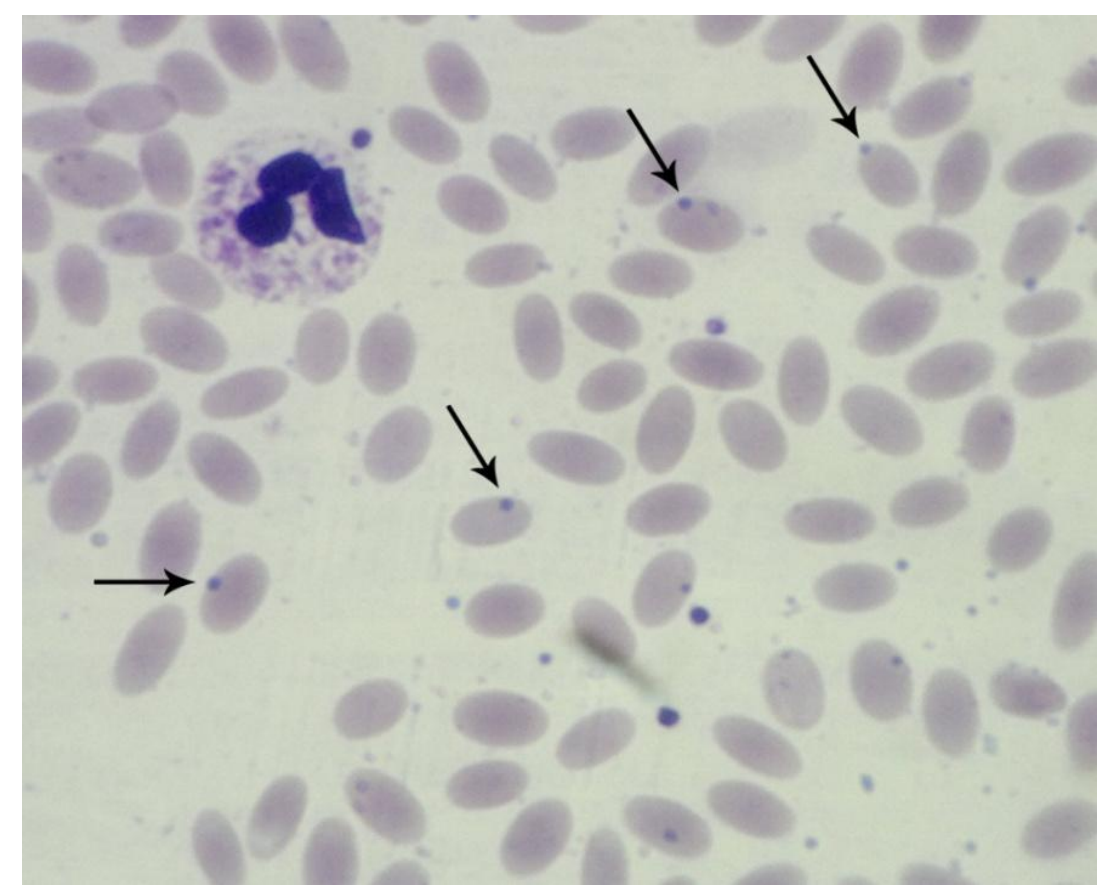

Fig.1. Anaplasma marginale inside RBCs in Giemsa stained blood film of camel.

(X 1000)

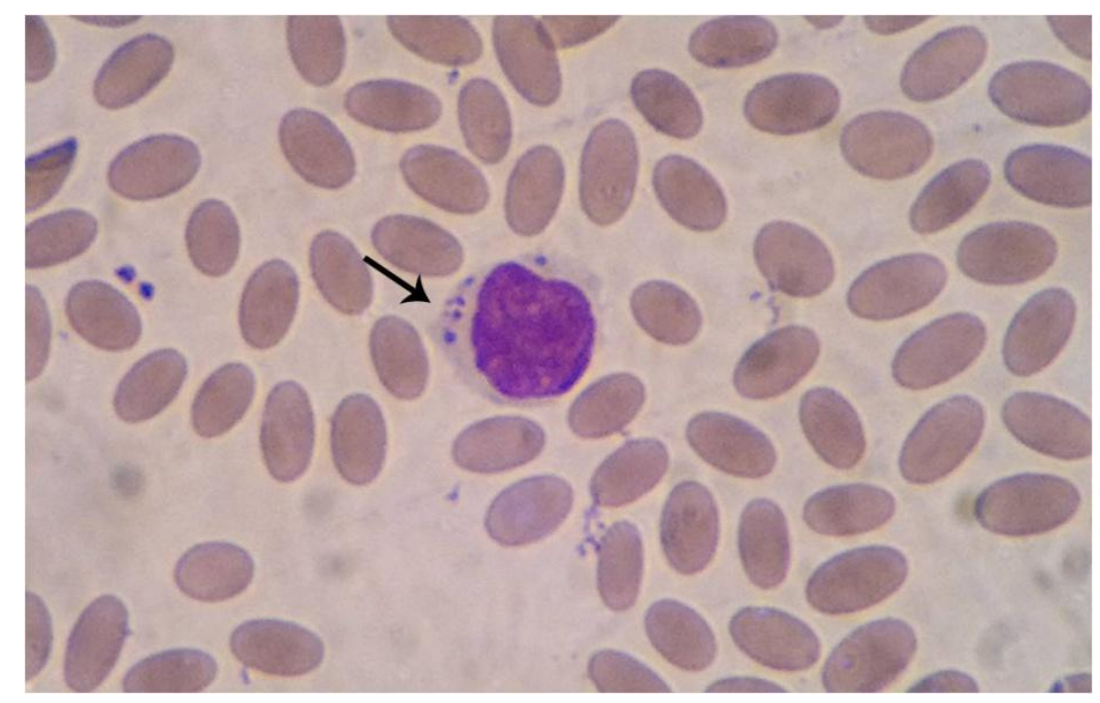

Fig. 2. Schizonts of Theileria (Kbb) inside lymphocyt in Giemsa stained blood film of camel. (X 1000)

Detection of $C$. psittaci antibodies in the collected serum samples by complement fixation test (CFT):

Table (2) showed that $28.3 \%$ (15/53) of examined serum samples were positive for the presence of $C$. psittaci antibodies using CFT. Positive samples titer with $1 / 32$ were detected in $8.8 \%(3 / 34)$ and $15.8 \%(3 / 19)$ in camels $\geq 5$ and $<5$ years respectively. 
Positive samples titer $\geq 1 / 64$ were detected in $8.8 \%(3 / 34)$ and $31.6 \%(6 / 19)$ in the same camel ages respectively.

Table 2. Detection of Chlamydia psittaci antibodies in the collected serum samples by complement fixation test (CFT).

\begin{tabular}{|l|c|c|c|}
\hline $\begin{array}{c}\text { Total No. of examined } \\
\text { samples }(53)\end{array}$ & Positive samples titers & Total positive No. & Positive \% \\
\hline 34 samples $\geq 5$ years & $1 / 32$ & 3 & $8.8 \%$ \\
\hline 19 samples $<5$ years & $1 / 32$ & 3 & $15.8 \%$ \\
\hline \hline 34 samples $\geq 5$ years & $\geq 1 / 64$ & 6 & $8.8 \%$ \\
\hline 19 samples $<5$ years & $\geq 1 / 64$ & 15 & $28.3 \%$ \\
\hline Total & & & $31.6 \%$ \\
\hline
\end{tabular}

\section{Detection of chlamydiae antigen using egg inoculation:}

Using Gimenez staining, chlamydial inclusions appeared in the collected yolk sac membranes as small, rounded red dots (Fig.3). The infected egg embryos appeared dwarfed with presence of hemorrhagic spots in the head and toes (Fig. 4).

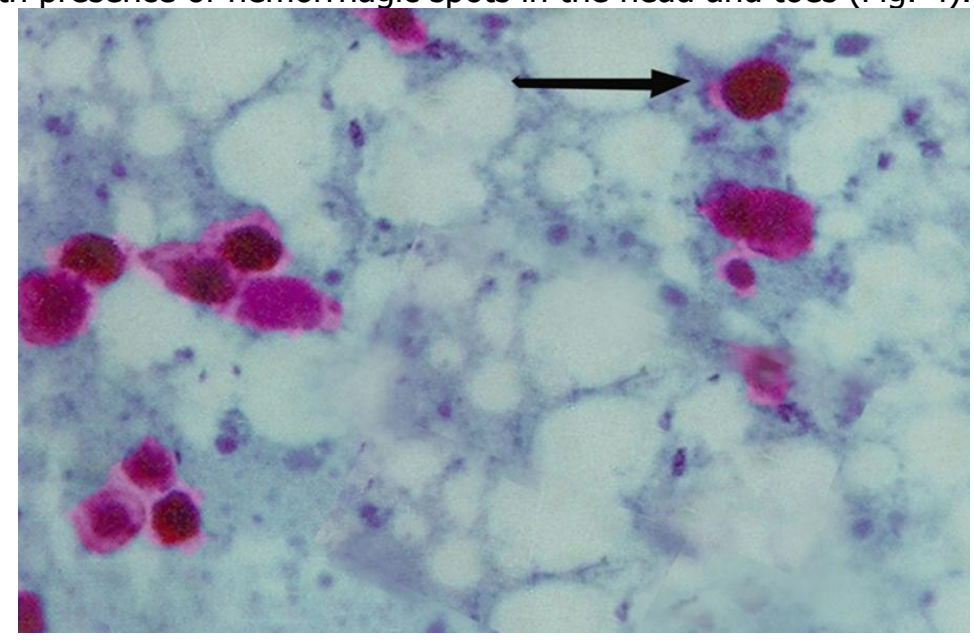

Fig. 3. The inclusion bodies in the infected yolk sac membrane stained with Gimenez stain. X1200. 


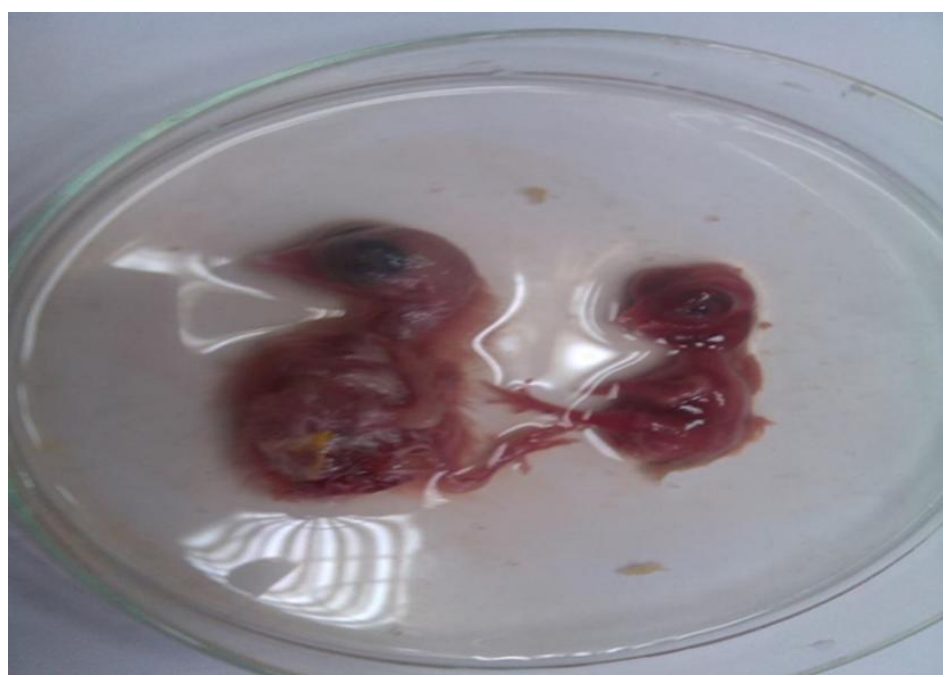

Fig. 4. The growth abnormalities, dwarfism and congestion of chicken embryo.

Table (3) showed that the chlamydial inclusion bodies within the examined samples in yolk sac by Gimenez stain detected in $45 \%(9 / 20)$ of vaginal swabs and in $20 \%(3 / 15)$ of internal organs.

Table 3. Direct detection of chlamydial inclusion bodies within the examined samples in yolk sac using Gimenez stain.

\begin{tabular}{|l|c|c|c|}
\hline \multicolumn{1}{|c|}{$\begin{array}{c}\text { Total No. of examined samples } \\
\text { (35) }\end{array}$} & $\begin{array}{c}\text { No. of negative } \\
\text { samples }\end{array}$ & No. of positive samples & Positive \% \\
\hline Vaginal swabs (20) & 11 & 9 & $45 \%$ \\
\hline Internal organs (15) & 12 & 3 & $20 \%$ \\
\hline Total & 23 & 12 & $34.3 \%$ \\
\hline
\end{tabular}

Table (4) illustrated history of abortion, stillbirths, death of camel calves within 6 months of birth and the still alive camel calves in 2013 and after treatment in 2014 and 2015. Number of aborted fetuses was 5 (26.3\%) in year 2013 and decreased during 2014 and 2015 to become 4 (20\%) and 1 (5.3\%) respectively. Number of stillbirths decreased from $3(15.8 \%)$ in 2013 to become 1 (5\% and $5.3 \%)$ in the next 2 years. Number of camel calves dead within 6 months of birth in years 2013 and 2014 were $10(52.6 \%)$ and $11(55 \%)$ respectively while no camels dead in 2015. Number of still alive camel calves in the farm improved as it increased from 1 (5.3\%) in 2013 to become 4 (20\%) and $17(89.5 \%)$ during the next 2 years. 
Table 4. History of abortion, stillbirths, death of camel calves and still alive ones in the farm during years from 2013 till 2015.

\begin{tabular}{|c|c||c|c||c|c||c|c||c|c|}
\hline Year & $\begin{array}{c}\text { No. of } \\
\text { Pregnant } \\
\text { camels }\end{array}$ & $\begin{array}{c}\text { No. of } \\
\text { aborted } \\
\text { fetuses }\end{array}$ & $\%$ & $\begin{array}{c}\text { No. of } \\
\text { Stillbirths }\end{array}$ & $\%$ & $\begin{array}{c}\text { No. of camel } \\
\text { calves dead } \\
\text { within } 6 \\
\text { months of } \\
\text { birth }\end{array}$ & $\%$ & $\begin{array}{c}\text { No. of } \\
\text { still alive } \\
\text { camel } \\
\text { calves }\end{array}$ & $\%$ \\
\hline 2013 & 19 & 5 & $26.3 \%$ & 3 & $15.8 \%$ & 10 & $52.6 \%$ & 1 & $5.3 \%$ \\
\hline $2014 *$ & 20 & 4 & $20 \%$ & 1 & $5 \%$ & 11 & $55 \%$ & 4 & $20 \%$ \\
\hline 2015 & 19 & 1 & $5.3 \%$ & 1 & $5.3 \%$ & -- & $0 \%$ & 17 & $89.5 \%$ \\
\hline
\end{tabular}

*The program of treatment started at the beginning of 2014 and repeated every 6 months

\section{DISCUSSION}

History of abortion, stillbirths and death of camel calves within 6 months of birth appeared in a farm in Mersa Matrouh in year of 2013. Laboratory diagnosis indicated the presence of Toxoplasma antibodies and infection with Theileria, Anaplasma and Chlamydia. Many authors recorded those infections in camels in different countries which cause the same history. Hayde and Pollak (2000), Trees and Williams (2005) and Hide et al. (2009) recorded that T. gondii cause abortion, vertical transmission, neonatal death, faetal abnormalities and congenital disease in animals and human. Ismael et al. (2014) found that Theileria infection in camels cause abortion and/or infertility. Baek et al. (2003) showed that abortion, stillbirths and vertical transmission could be occur in cows infected with Theileria spp. UrdazRodríguez et al. (2009) and Hairgrove et al. (2015) stated that Anaplasma is highly pathogenic for ruminants and cause abortion and fetal death.

In the studied farm, there was no history of previous treatment for toxoplasmosis, so the detection of Toxoplasma antibodies by LAT indicated the presence of previous Toxoplasma infection or recent infection. Toxoplasma antibodies were higher in camels $\geq 5$ years $(70.6 \%)$ than those $<5$ years $(42.1 \%)$. Elamin et al. (1992) and Hamidinejat et al. (2013) recorded the occurrence of T. gondii antibodies was greater in older camels and that might be due to the longer period of exposure to infection in older camels compared to young ones. Also, it may be due to the vertical transmission from mother to fetus through placenta (Ebbesen, 2000).

In the present study, there is no great difference between rate of infection with Theileria, Anaplasma and mixed infection with them in adult and young camels before treatment. After treatment the infection rate decreased to $0 \%$ in both adult and young camels.

The present study was primarily undertaken to determine the prevalence of chlamydiosis in camels in Egypt. The results suggest that camels are an ideal reservoir of Chlamydia species and thus shed the organisms in their excreta. The shedding of Chlamydia by wild birds throughout the Egyptian habitat may trigger another zoonotic potential to humans existing at their vicinity. The organism is also important from a zoonotic standpoint, particularly as an occupational hazard. 
Ali et al. (2012) reported that C. abortus may be responsible for the spreading of the ovarian hydrobursitis syndrome in dromedaries. In the United Arab Emirates, Wernery and Wernery (1990) detected anti-chlamydial antibodies in the sera of both breeding and racing camels, with respective prevalence rates of 24 and 15\%. In Saudi Arabia, a serological prevalence of $19.4 \%$ was reported for chalmydiosis in camels with a higher prevalence in females than males (Hussein et al., 2008). In Libya, Elzlitne and Elhafi (2016) showed that $12.25 \%$ of tested camels were positive for antiChlamydia antibodies and it was higher in females (14.0\%) than males (5.0\%). Chlamydial infection has been associated with abortion in New World camelids, and the prevalence of chlamydiosis was higher in females than in males (Wernery and Wernery, 1990 and Ali et al., 2012).

Culture of chlamydiae is difficult and infrequent because of the obligate intracellular nature of the bacteria and the hazard exposed to researchers (Messmer et al., 2009). Cell culture or egg inoculation is the gold standard for diagnosis of Chlamydia spp. Isolation of viable Chlamydia spp. requires infection of embryonic egg or cell culture (Condon and Oakey, 2007).

After treatment program followed in the present work, the number of aborted fetuses decreased from $26.3 \%$ in year 2013 to become $20 \%$ and $5.3 \%$ in 2014 and 2015 respectively. The stillbirths also decreased from $15.8 \%$ to $5 \%$ and $5.3 \%$ in the same years. Percent of camel calves dead within 6 months of birth were $52.6 \%$ and $55 \%$ in 2013 and 2014 respectively and decreased to $0 \%$ in 2015 . On the other hand, the percent of still alive camel calves increased from $5.3 \%$ in 2013 to $20 \%$ and $89.5 \%$ in 2014 and 2015 respectively.

In the present study, the program of treatment included trimethoprim plus sulphadiazine, buparvaquone, imidocarb dipropionate and oxytetracycline succeeded in treatment and control of toxoplasmosis, theileriosis, anaplasmosis and chlamydiosis. Bawazeer and Nizamuddin (2008) and Felix et al. (2014) tried trimethoprim in combination with sulfonamide in treatment of toxoplasmosis with various therapeutic efficacies. Singh et al. (1993) and Muraguri et al. (2006) reported the use of buparvaquone with success in treatment of theileriosis in cattle. McHardy and Simpson (1974) and Patarroyo et al. (1982) used imidocarb dipropionate in the treatment of anaplasmosis.

It could be suggested that the programme of treatment with trimethoprim plus sulphadiazine, buparvaquone, imidocarb dipropinate and oxytetracycline may offer an effective procedure to control history of abortion, stillbirths and death of camel calves caused by toxoplasmosis, theileriosis, anaplasmosis and chlamydiosis. Control of those diseases can help camels to restore their activity and consequently regain their health and increase the economics of animal production in the farm. 


\section{REFERENCES}

1. Ali A., F. Al-Sobayil, K. Hassanein and A. Al-Hawas. 2012. Ovarian hydrobursitis in female camels (Camelus dromedarius): The role of Chlamydophila abortus and a trial for medical treatment. Theriogenology, 77: 1754-1758.

2. Aljumaah S. and F.H. Mansour. 2012. Serological prevalence of ovine and caprine chlamydophilosis in Riyadh region, Saudi Arabia. Afr. J. Microbiol. Res, 6(11): 2654-2658.

3. Andersen A.A. 1998. Chlamydiosis. In: A laboratory manual of the isolation and identification of avian pathogens. $4^{\text {th }}$ ed. Kendall Hunt Publishing, Dubuque, Iowa, USA.

4. Baek B.K., K.B. Soo, J.H. Kim, J. Hur, B.O. Lee, J.M. Jung, M. Onuma, A.O. Oluoch, C. Kim and I. Kakoma. 2003. Verification by polymerase chain reaction of vertical transmission of Theileria sergenti in cows. Can. J. Vet. Res., 67:278282

5. Bastos A.D.S., O.B. Mohammed, N.C. Bennett, C. Petevinos and A.N. Alagaili. 2015. Molecular detection of novel Anaplasmataceae closely related to Anaplasma platys and Ehrlichia canis in the dromedary camel (Camelus dromedarius). Vet. Microbiol., 179: 310-314.

6. Bawazeer A.M. and S.H.M. Nizamuddin. 2008. Clinical experience with trimethoprim-sulfamethoxazole and prednisolone in the treatment of ocular toxoplasmosis with zone-1 posterior pole and peri-papillary lesions. J. T. U. Med. Sci., 3(1): 16-24.

7. Belkahia H., M. Ben Said, L. Sayahi, A. Alberti and L. Messadi. 2015. Detection of novel strains genetically related to Anaplasma platys in Tunisian one-humped camels (Camelus dromedarius). J. Infect. Dev. Ctries., 9(10):1117-1125.

8. Black C.M. 1997. Current method of laboratory diagnosis of Chlamydia trachomatis infection. Clin. Micro. Rev., 10: 160-184.

9. Condon K. and J. Oakey. 2007. Detection of Chlamydiaceae DNA in veterinary specimens using a family-specific PCR. Lett. Appl. Microbiol., 45 (2): 121-127.

10. Ebbesen P. 2000. Placenta physiology. In: Ambroise-Thomas P., Petersen E., editors. Congenital toxoplasmosis: scientific background, clinical management and control. Paris: Springer-Verlag, pp. 27-35.

11. Edwin H.L. and J.S. Nathalie. 1979. Diagnostic procedure for viral, rickettsial and chlamydial infection, 5th ed. American Public Health Association, New York and Washington, pp. 1015.

12. Elamin E.A., S. Elias, A. Daugschies and M. Rommel. 1992. Prevalence of Toxoplasma gondii antibodies in pastoral camels (Camelus dromedarius) in the Butana plains, Mid-Eastern Sudan. Vet. Parasitol., 43:171-175. 
13. El-Fayoumy M.M., T.R. Abou Elnga, S.M.M. Abd El-Baky and T.A. Abdou. 2005. Prevalence of camel theileriosis and its vector tick in North Coast of Egypt. J. Egypt. Vet. Med. Assoc., 65: 291-302.

14. El-Refaii M.A.H., A.A. Wahba and G.J. Shehab. 1998. Studies on Theileria infection among slaughtered camels in Egypt. Egypt. J. Med. Sci., 19(1): 1-17.

15. Elzlitne R. and G. Elhafi. 2016. Seroprevalence of Chlamydia abortus in camel in the western region of Libya. J. Adv. Vet. Anim. Res., 3(2): 178-183.

16. Felix J.P.F, R.P.C. Lira, R.S. Zacchia, J.M. Toribio, M.A. Nascimento and C.E.L. Arieta. 2014. Trimethoprim-sulfamethoxazole versus placebo to reduce the risk of recurrences of Toxoplasma gondii retinochoroiditis: randomized controlled clinical trial. Am. J. Ophthalmol., (157)4: 762-766.

17. Gimenez D.F. 1964. Staining rickettsiae in yolk sac culture. Stain Technology 39: $135-140$.

18. Hairgrove T., M. E. Schroeder, C.M. Budkec, S. Rodgers, C. Chung, M.W. Ueti and M.A. Bounpheng. 2015. Molecular and serological in-herd prevalence of Anaplasma marginale infection in Texas cattle. Prev. Vet. Med., 119: 1-9.

19. Hamidinejat H., M. Ghorbanpour, A. Rasooli, M. Nouri, S. Hekmatimoghaddam, M.M. Namavari, M. Pourmehdi-Borojeni and A. Sazmand (2013): Occurrence kof anti-Toxoplasma gondii and Neospora caninum antibodies in camels (Camelus dromedaries) in the center of Iran. Turk. J. Vet. Anim. Sci., 37: 277-281.

20. Hayde M. and A. Pollak (2000): Clinical picture: neonatal signs and symptoms. In: Ambroise-Thomas P., Petersen E., editors. Congenital toxoplasmosis: scientific background, clinical management and control. Paris: Springer-Verlag France, pp. 153-64.

21. Hide G., E. Morley, J. Hughes, O. Gerwash, M. Elmahaishi, K. Elmahaishi, D. Thomasson, E. Wright, R. Williams and R. Murphy. 2009. Evidence for high levels of vertical transmission in Toxoplasma gondii. Parasitol., 136: 1877-1885

22. Hilali M., S. Romand, P. Thulliez, O.C.H. Kwok and J.P. Dubey (1998): Prevalence of Neospora caninum and Toxoplasma gondii antibodies in sera from camels from Egypt. Vet. Parasitol., 75:269-271.

23. Hussein M.F., M. Alshaikh, M. Gad El-Rab, R. Aljumaah, A. Gar El-Nabi and Abdel Bagi (2008): Serological prevalence of $Q$ fever and chlamydiosis in camels in Saudi Arabia. J. Anim. Vet. Adv., 7: 685-688.

24. Ismael A.B., A.A. Swelum, A.F. Khalaf and M.A. Abouheif. 2014. Clinical, haematological and biochemical alterations associated with an outbreak of theileriosis in dromedaries (Camelus dromedarius) in Saudi Arabia. Pak. Vet. J., 34(2): 209-213. 
25. Klun I., D.O. Djurkovic, R.S. Katic and A. Nikolic. 2006. Cross-sectional survey on Toxoplasma gondii infection in cattle, sheep and pigs in Serbia: seroprevalence and risk factors. Vet. Parasitol., 135: 121-131.

26. McHardy N. and R.M. Simpson. 1974. Imidocarb dipropionate therapy in Kenyan anaplasmosis and babesiosis. Trop. Anim. Hith. Prod., 6: 63-70.

27. Messmer T.O., S.K. Skelton, J.F. Moroney, H. Daugharty and B.S. Fields. 2009. Application of a nested, multiplex PCR to psittacosis outbreaks. J. Clin. Microbiol., 35:2043-2046.

28. Michael S., A. EL Refaii and T. Morsy. 1977. Incidence of Toxoplasma antibodies among camels in Egypt. J. Egypt Soc. Parasit., 7: 129-132.

29. Muraguri G.R., P.N. Mgumi, D. Wesonga, S.G. Ndungu, J.M. Wanjohi, K. Bang, A. Fox, J. Dunne and N. McHardy. 2006. Clinical efficacy and plasma concentrations of two formulations of buparvaquone in cattle infected with East Coast fever (Theileria parva infection). Res. Vet. Sci., 81(1): 119-126.

30. Patarroyo J.H., M.F. Ribeiro and M.I. Vargas. 1982. Effect of imidocarb dipropionate in brazilian anaplasmosis and babesiosis. Trop. Anim. Hlth. Prod., 14: 234.

31. Pierre P. and T. Michel. 1993. Methods and Techniques in virology. Marcel Dekker, Inc. New york. Basel. Hong Kong.

32. Reinhold P., K. Sachse and B. Kaltenboeck. 2011. Chlamydiaceae in cattle: Commensals, trigger organisms, or pathogens. The Veterinary Journal, 189: 257-267.

33. Singh D.K., M. Thakur, P.R.S. Raghav and B.C. Varshney. 1993. Chemotherapeutic trials with four drugs in crossbred calves experimentally infected with Theileria annulata. Res. Vet. Sci. 54: 68-71.

34. Trees A.J. and D.J. Williams. 2005. Endogenous and exogenous tranceplacental infection in Neospora caninum and Toxoplasma gondii. Trends Parasitol., 21: 558-561.

35. Urdaz-Rodríguez J.H., G.T. Fosgate, A.R. Alleman, D.O. Rae, G.A. Donovan and P. Melendez. 2009. Seroprevalence estimation and management factors associated with high herd seropositivity for Anaplasma marginale in commercial dairy farms of Puerto Rico. Trop. Anim. HIth. Prod., 41: 1439-1448.

36. Wernery U. and R. Wernery. 1990. Seroepidemiologic studies of the detection of antibodies to Brucella, Chlamydia, Leptospira, BVD/MD virus, IBR/IPV virus and enzootic bovine leukosis virus (EBL) in dromedary mares (Came/us dromedarius). Deutsche Tierartztliche Wochenschrift, 97(3): 134-135. 


\section{دراسات عن مسببات الإجهاض في الإبل المغربي}

أحمد عثمان أحمد عثمان' - حسن عبده المتولي' - أحمد أنور وهبه" - سماح فاروق حفني؛

$$
\begin{aligned}
& \text { ا ـ قسم الخدمات البيطرية (بكتريولوجي) - معهد بحوث الإنتاج الحيواني }
\end{aligned}
$$

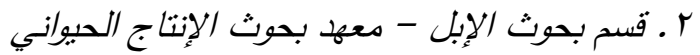

$$
\begin{aligned}
& \text { r م قسم الطفيليات - معهُ بحوث صحة الحيوان } \\
& \text { ح. وحدة الكلاميبيا - معهد بحوث صحة الحبوان }
\end{aligned}
$$

حدثت حالات إجهاض وخروج أجنة نافقة ونفوق لإبل مولودة خـلال الستة أثشهر الأولي من

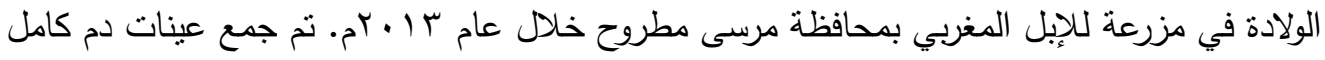

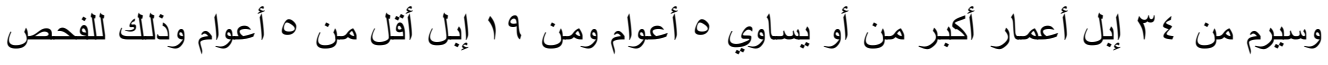

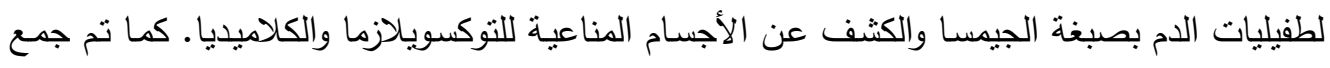

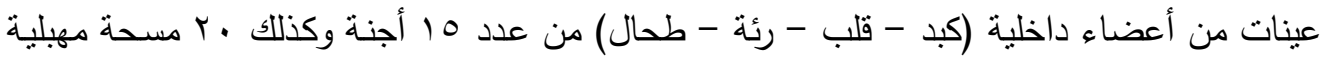
من إناث الإبل المجهضـة وذلك لعزل الكلاميديا عن طريق الحقن في البيض المخصب. بالفحص

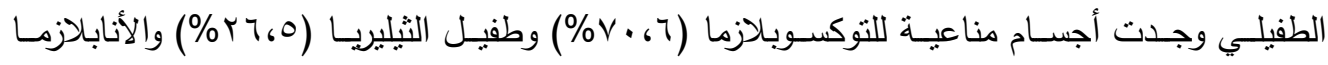

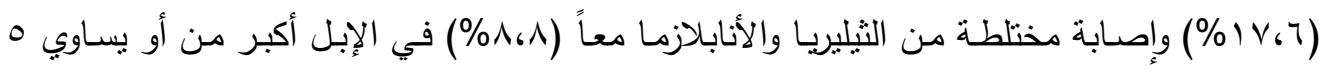

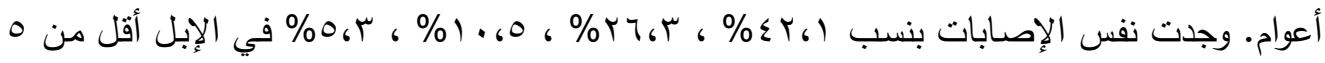

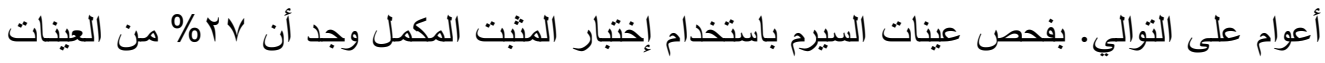
إيجابية للأجسام المناعية للكلاميديا سيتاسي. وجدت أجسام محورية للكلاميديا في 0 ؛ \% من المسحات

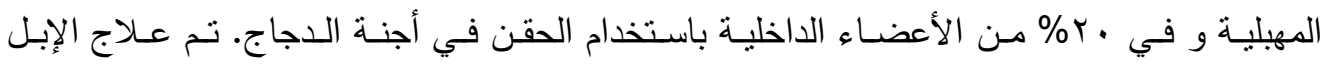
بالمزرعة دورياً كل 7 أنشهر بالكولييريم ، البيوتالكس ، الإيميزول ، الألاميسين. وجد إنخفاض في في عداه

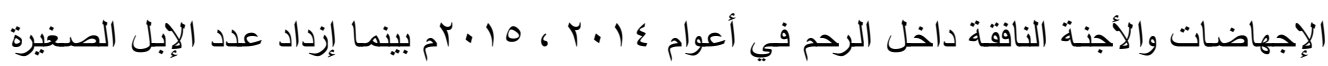
التي استمرت على قيد الحياة في نفس الأعوام. لم ينفق إي عدد من الإبل الصغيرة خلادل الستة الستة أنشهر

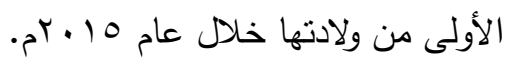

